\title{
Identification of a circular structure in eastern Pomerania (northern Poland) - a hypothesis of its origin
}

\author{
Grzegorz UŚCINOWICZ ${ }^{1, *}$ \\ 1 Polish Geological Institute - National Research Institute, Marine Geology Branch, Kościerska 5, 80-328, Gdańsk, Poland
}

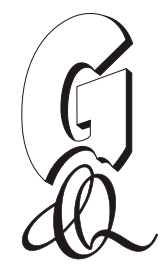

\begin{abstract}
Uścinowicz, G., 2017. Identification of a circular structure in eastern Pomerania (northern Poland) - a hypothesis of its origin. Geological Quarterly, 61 (1): 205-213, doi: 10.7306/gq.1332

The possible existence of a circular structure in the Kościerzyna region (northern Poland) was suggested in two papers in the 1980s. The current studies were aimed at verifying this hypothesis. Analysis of a digital terrain model of the pre-Quaternary surface relief as well as of the present terrain revealed the existence of a large structure of ca. $50 \mathrm{~km}$ in diameter. Its geometry was established based on a model of the Neogene/Pliocene surface and identifiable lineaments. Its characteristic feature is the presence of rim-like forms, an internal plateau, and a "high" in the centre. The structure is estimated to date from before the Pleistocene. The circular structure has been reshaped by glacial erosion and accumulation, and is now buried under Quaternary deposits. The existence of the Kościerzyna circular structure was confirmed by conducted studies, but my hypothesis of an impact origin is still uncertain and needs to be confirmed by future research.
\end{abstract}

Key words: circular structure, northern Poland, Neogene, Quaternary.

\section{INTRODUCTION}

Aerial and satellite images have revealed several times the existence of circular structures at the Earth's surface that had not been detected previously by traditional cartographical work. Apart from the best-known and well-studied cases that used a variety of methods, their origin is not yet fully clear (Saul, 1978; Taud and Parrot, 1992; Brink et al., 1997; Turtle and Pierazzo, 1998; Riller, 2005; Juhlin et al., 2012).

The increase in interest in structures with a circular or elliptical outline took place simultaneously with the development of new remote sensing methods based on satellite images. This enabled the recognition of structures of considerable size, from tens to hundreds of kilometres in diameter. The genesis of such forms has been discussed in numerous studies. They have been ascribed to endogenic processes such as volcano-tectonics, intrusions, and salt tectonics, but also to exogenic processes such as karstification or the impact of meteorites (Goulty et al., 2001; Bertoni and Cartwright, 2005; Matton et al., 2005; French and Koeberl, 2010; Alsouki et al., 2011). Several impact structures that are known from Europe were formed under different conditions, and their age varies greatly, just like their state of preservation and their sizes from relatively small to considerable (Pohl et al., 1977; Stankowski, 2001; Stoffler et al., 2001; Surroja and Surroja, 2010; Juhlin et al., 2012; Uścinowicz, 2014).

\footnotetext{
*E-mail: grzegorz.uscinowicz@pgi.gov.pl
}

Received: February 12, 2016; accepted: June 13, 2016; first published online: December 2, 2016
A number of circular forms, sometimes interpreted as impact structures, can also be found in the territory of Poland. Numerous examples occur in the Sudety Mountains (Doktór and Graniczny, 1983; Przybylski and Badura, 2004), but similar structures are also present throughout the rest of the country. One of the best visible is the circular structure near Kościerzyna, which was recognized from Landsat satellite images and confirmed by analysis of lineaments (Doktór and Graniczny, 1983). Little was known thus far about this structure, and its origin is not yet clear. Actually, only a single study was published about this topic; it ascribed the structure to a large meteorite impact (Doktór et al., 1989). It should be noted, however, that this preliminary interpretation was based on a fairly general study and the identification of the origin will require considerably deeper-going studies.

The presence of this circular structure with its significant diameter of approx. $50 \mathrm{~km}$, which is visible within relatively young (Neogene/Pleistocene) sediments, raises legitimate questions about its origin. Answering these questions requires a better insight into the deep geological structure of the area as well as into the changes that the bedrock may have undergone. Such studies will lead to more understanding of the sedimentation processes, the transformation of the substrate, and the morphogenesis of northern Poland. The aim of the present study is therefore to identify the lateral boundaries of the Kościerzyna circular structure, its internal geometry, and to discuss its hypothetical genesis.

\section{GEOLOGICAL SETTING}

The study area is located in the Lake District of eastern

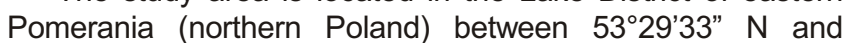




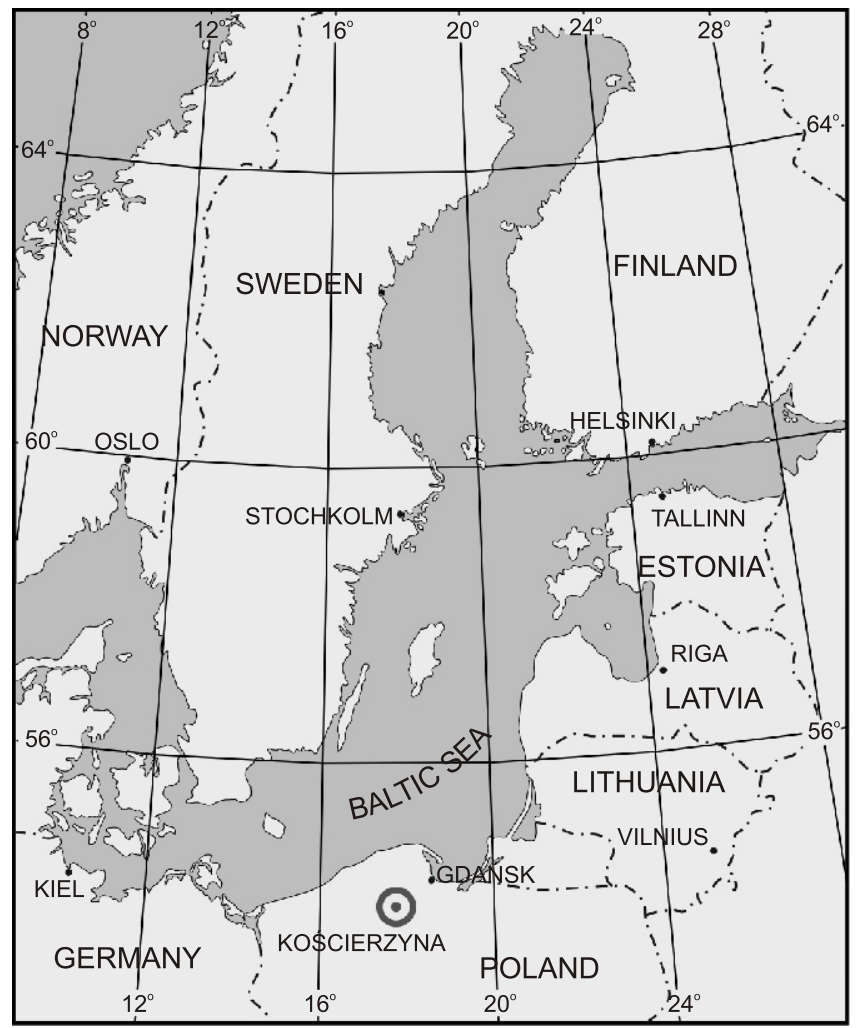

Fig. 1. Location of the study area

$54^{\circ} 40^{\prime} 35^{\prime \prime} \mathrm{N}$, and between $17^{\circ} 2^{\prime} 06^{\prime \prime} \mathrm{E}$ and $18^{\circ} 43^{\prime} 14^{\prime \prime} \mathrm{E}$ (Fig. 1). It is characterized by significant differences in the nature of the surface features. During the Quaternary, Scandinavian ice sheets several times covered the area and the landscape was shaped by alternations of glaciations and deglaciations. The final morphological features originated during the retreat of the last Weichselian ice sheet in the investigated area, which took place approx. 17,000-16,000 years ago (Mojski, 1980; Marks, 2010). The area under discussion can be subdivided into several parts regarding their morphogenesis. There is a clearly visible surface of moraine upland in the northern part of the area. Its southern boundary (range of the youngest Pomeranian Phase) bends toward the north. There are isolated morainic sheets in the central part of the area (SW of Kościerzyna). The elevation of the morainic upland commonly reaches over $200 \mathrm{~m}$ a.s.I. and the highest top (Wieżyca Hill), $329 \mathrm{~m}$ a.s.I., is located in the NE part of the area. The southwestern part of the area also consists of a morainic upland, but is genetically linked to an earlier phase of the Weichselian Glaciation. The central and southeastern parts consist of a wide and relatively flat sandy sandur plain at an elevation of 150-180 $\mathrm{m}$ a.s.I. The whole area was crossed by numerous meltwater streams (tunnel valleys and subglacial channels) of different sizes (Mojski, 1973, 1978a, b, 1979; Petelski, 2011), as well as by postglacial streams (Fig. 2).

Geologically, the area consists of two main structural units which differ particularly in terms of the deep geological structure. The crystalline basement, which is composed of Proterozoic rocks, ascends from a depth of ca. $4500 \mathrm{~m}$ b.g.l. in the NE to ca. $8000 \mathrm{~m}$ b.g.I. in the SW. This results in a complex thickness pattern of the Paleozoic-Mesozoic sedimentary succession, which is several kilometres thick. The top of the Creta- ceous, which is situated constantly at $75-120 \mathrm{~m}$ b.s.l., is overlain by Paleocene, Eocene, Oligocene and Miocene/Pliocene sands, silts and clays interbedded with lignites. The Quaternary overlies mainly Miocene and, locally, Oligocene sands, silts and clays with a limnic and fluvial facies. The top surface of the Miocene shows relief variations exceeding 100 m (Mojski, 1973, 1978a, b, 1979; Znosko et al., 1998; Gałązka and Marks, 2009). The Pliocene deposits are represented by a thin layer of fluvial quartz-rich sands (Kramarska et al., 2015), but they are often misinterpreted in eastern Pomerania as Miocene sands.

The Quaternary sediments are up to $200 \mathrm{~m}$ thick in this area. Deposits of almost all the Pleistocene glaciations that covered the Polish Lowlands have been identified (Mojski, 1973, $1978 a, b, 1979)$. The moraines formed by the ice sheet are composed of sands, loamy sands and tills, while the outwash plains (sandurs) consist mainly of sands and gravel. Erosional valleys, channels (tunnel valleys and subglacial channels), kettle-like depressions, and fluvial valleys are filled with thin (up to several metres) Holocene organic and mineral sediments. The Quaternary and the underlying Miocene/Pliocene deposits are unlithified, relatively soft rocks and rocks with a low degree of diagenesis, and their total thickness is up to $350-400 \mathrm{~m}$.

\section{MATERIAL AND METHODS}

The study was based on several fundamental analytical methods. First, the digital terrain model (DTM) was analysed using various geoprocessing techniques, for instance: analysis of contour lines (isohypses) and axes of valleys, identification of slope gradient, and determination of downslope direction.

The shaded and coloured digital terrain model with a resolution of $30 \times 30 \mathrm{~m}$ was used during the analysis with the ArcMap software in the following way:

- first, the parameters affecting the vividness and readability of the digital model were adjusted. These parameters included the colour scale, contrast and contours;

- second, GIS-based features from a raster surface have been created. These features were subsequently used for morphological analysis and interpretation of the general course of morpholineaments - linear topographic features.

The next step was the analysis of archived data from 249 boreholes. The data are stored in the Central Geological Database as well as in the National Geological Archive (Appendix $\left.1^{*}\right)$. These studies were based mainly on verification of the location of the boreholes, and of the data on the thickness of the Quaternary succession and the lithology of both the Quaternary and underlying sediments. This enabled the selection of reliable archived research data that could be used as the basis for further analysis.

Subsequently, the available drilling records were used to prepare a map of the pre-Quaternary surface. A model of the pre-Quaternary surface and cross-sections were prepared using Surfer 12 software. This model was generated using the Minimal Curvature interpolation method. During the process of space interpolation, a grid of $1000 \times 1000 \mathrm{~m}$, which gives $131 \times$ 110 data rows, was created (Table 1). This process led to a substantial density of data within the data grid, despite the irregular distribution of boreholes. As a consequence of the irregular distribution of the data points (location of boreholes), there is the risk that interpolation errors may occur where few data points are available. The handling of the grid data was therefore 


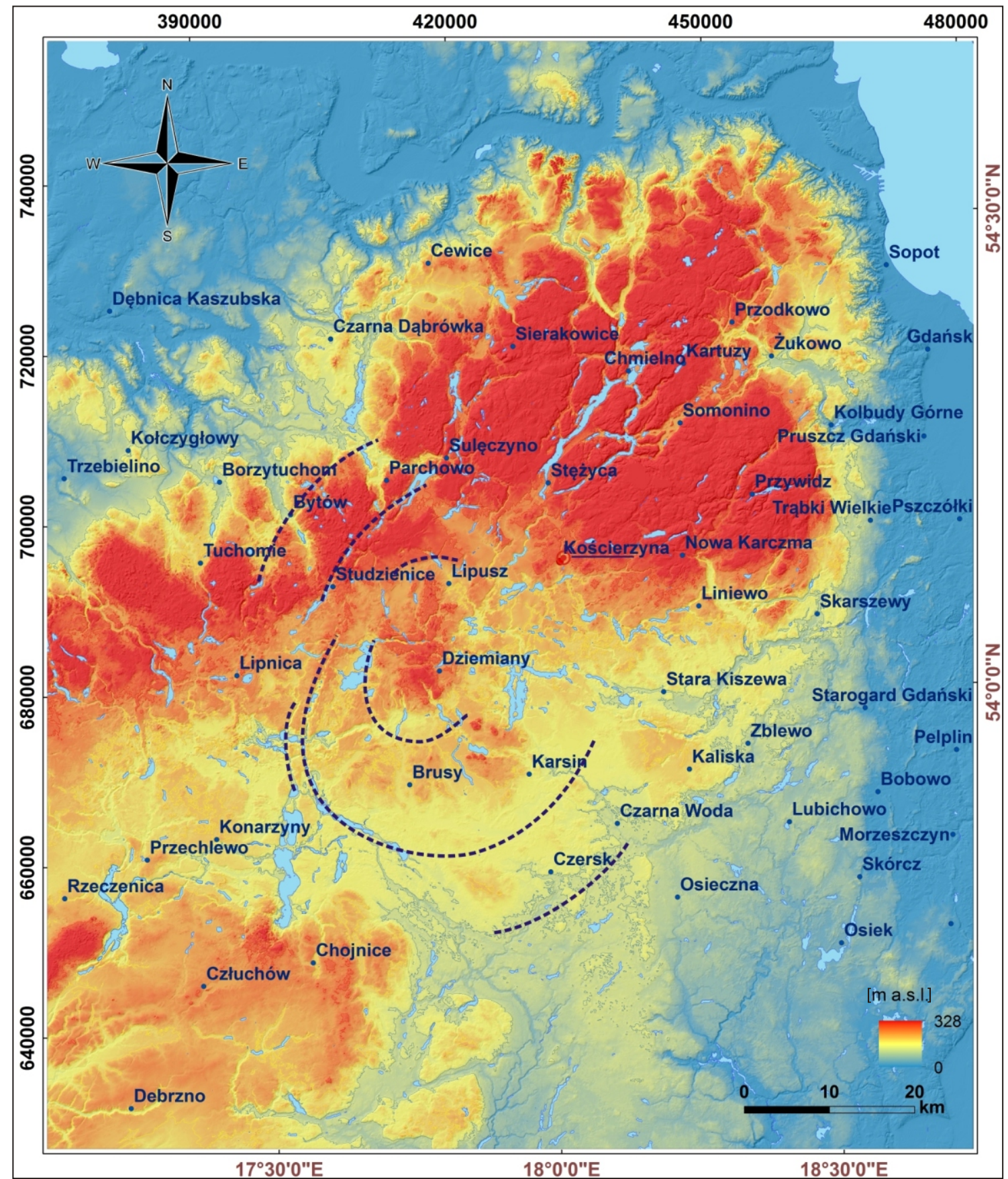

Fig. 2. Digital terrain model of the study area

The DTM was used for GIS-based analytical techniques; dashed lines indicate semicircular elements that presumably represent the limits of the feature under discussion 
Ta ble 1

Interpolation grid information

\begin{tabular}{|c|c|}
\hline Grid Size: & 131 rows $\times 110$ columns \\
\hline Total Nodes: & 14410 \\
\hline Filled Nodes: & 14410 \\
\hline Blanked Nodes: & 0 \\
\hline \multicolumn{2}{|c|}{ Grid Geometry } \\
\hline X Minimum: & 373300 \\
\hline X Maximum: & 482000 \\
\hline X Spacing: & 997.24770642202 \\
\hline Y Minimum: & 627000 \\
\hline Y Maximum: & 757000 \\
\hline Y Spacing: & 1000 \\
\hline \multicolumn{2}{|c|}{ Univariate Grid Statistics Z } \\
\hline Minimum: & -85 \\
\hline Maximum: & 257 \\
\hline Mean: & 34.6462674166 \\
\hline Median: & 28.2836027224 \\
\hline Variance: & 3875.46858923 \\
\hline Standard Deviation: & 62.2532616755 \\
\hline Interquartile Range: & 82.4612850444 \\
\hline Range: & 342 \\
\hline Mean Difference: & 69.525882111 \\
\hline $\begin{array}{l}\text { Median Abs. Devia- } \\
\text { tion: }\end{array}$ & 40.7791005206 \\
\hline $\begin{array}{l}\text { Average Abs. Devia- } \\
\text { tion: }\end{array}$ & 49.0779382907 \\
\hline Standard Error: & 0.518597143427 \\
\hline Skewness: & 0.396258809126 \\
\hline Kurtosis: & 3.5058194206 \\
\hline
\end{tabular}

performed by recalculating the maximum and minimum values of the Neogene surface level, so that they corresponded with the actual minimum and maximum values determined from the borehole data. Finally, the data grid was subjected to filtering using a linear convolution filter, resulting in smoothing of the final product.

\section{RESULTS}

SPATIAL ANALYSIS

Analysis of the digital terrain model enables identification of linear morpholineaments (topographic features expressed in the course of river and lake valleys, slope contours, hill ridges, etc.), radiating from the area of the structure under consideration. Lineaments of local and regional scale reach a length of up to tens of kilometres in the study area. The lineaments are reflected in the morphology by the course of the river valleys and lake valleys, which are elements of the glacial relief (a system of subglacial channels), as well as in the isohypses (Fig. 3). The system of radiating linear morpholineaments can be regarded as the underlying geological structure. The structure could predispose the subglacial water circulation that shaped the modern course of the river and lake valleys.

It is worthwhile to mention that, in addition to the straight lineaments, it is possible to distinguish semicircular elements (also resulting from the morphological patterns) reflecting the partial limits of the structure under consideration. These semicircular patterns are controlled by the palaeostructure buried under the Quaternary deposits. Generally, a northwestern arch can be distinguished. Its course can be determined starting from the southern side of the town of Bytów, continuing north, and then turning to the north-east. A southern arc takes an open form on the north side and passes the village of Brusy in a semicircular pattern (see Fig. 2).

The whole system of these lineaments indicates partial boundaries of the structure with a probable diameter of ca. $50 \mathrm{~km}$.

\section{THE PRE-QUATERNARY SURFACE MODEL}

The model of the Miocene surface reveals the existence of a deep, approximately circular depression. Its approximate boundary underlies the town of Bytów and the villages of Sierakowice, Somonino, Stara Kiszewa, Karsin and Brusy. The inner contour of the structure can also be determined by the course of the isohypses of 10-30 m a.s.I, which reflect the pre-Quaternary surface. The outer contour can be visualized by the course of the isohypses of 60-110 m a.s.l., which reflect the Neogene surface (Fig. 4). The boundary of the depression can be determined only at a general level and suggests a diameter of $\sim 50 \mathrm{~km}$. Its characteristic feature is the presence of a central "high". The "high" was identified in boreholes showing that the top of the Neogene deposits occurs at an elevation of ca. $80 \mathrm{~m}$ a.s.l. The relatively flat bottom of the depression reaches $85 \mathrm{~m}$ b.s.l. in the east, while in the western part it ascends to ca. $60 \mathrm{~m}$ b.s.l. The whole structure is slightly elongated towards the east. The morphology of this feature is well visible on morphological cross-sections (Fig. 5); these show the rims and the central "high". However, the image of the circular structure resulting from the pre-Quaternary surface model is not entirely consistent with the boundaries visible in the terrain. While the western borders are more or less consistent, this is not the case for the NE and $\mathrm{E}$ limits. This is probably due to the general appearance of the model.

\section{DISCUSSION}

The existence of a circular structure of significant size could be caused by a variety of factors. In principle, it might be the effect of igneous (magmatic) intrusion in deep strata, volcanism, or halokinesis (a salt dome). Some of these contributing factors can produce both similar morphological patterns, characterized by a radial lineaments system, and a circular outline of the surface feature. Furthermore, the structure might, also in principle, be a result of karstification. None of these concepts is, however, appropriate in this case. Firstly, no indications for igneous intrusions have been found in this area. Moreover, it is an aseismic zone, so it is free of significant tectonic activity. Secondly, salt domes do not occur in this area. The salt domes located a few tens of kilometres to the SW of the centre of the Kościerzyna structure are related to the Mid-Polish Through (Czapowski and Bukowski, 2010; Pietsch et al., 2012; Marzec et al., 2013). These salt structures are characterized by elliptic NW-SE-trending shapes. Moreover, they have a much smaller size, ca. $1-5 \mathrm{~km}$. Thirdly, karst must also be excluded for geological reasons (absence of rocks that are susceptible to dissolution). In summary, there are no indications suggesting that the structure is associated with intrusion, volcanic activity, another endogenic factor, or with an exogenic factor such as karst. 


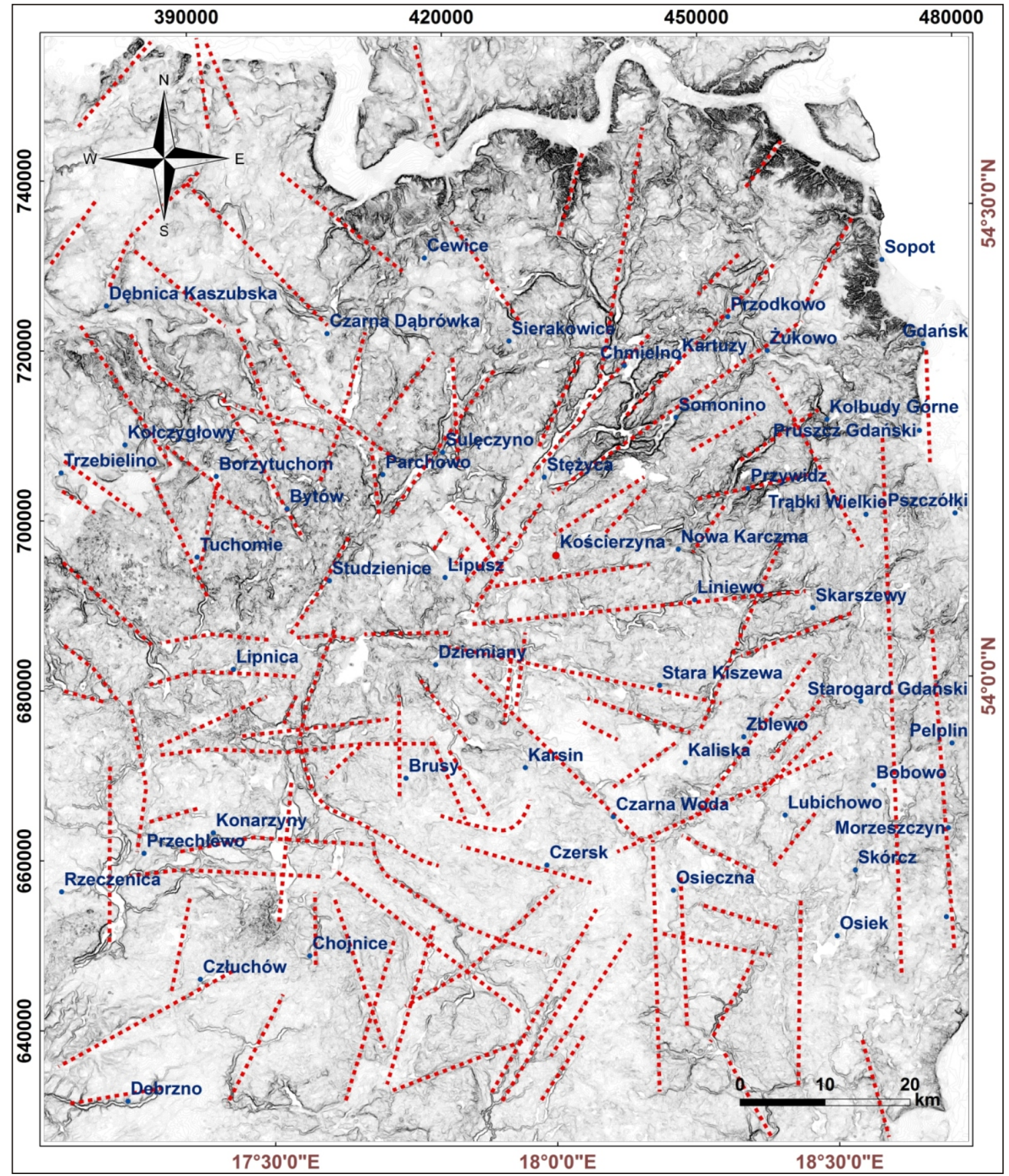

Fig. 3. Map of morpholineaments against the background of slope-shaded relief

Dashed lines indicate the general orientation of lineaments that are interpreted as derived from the course of river and lake valleys as well as from isohypses 


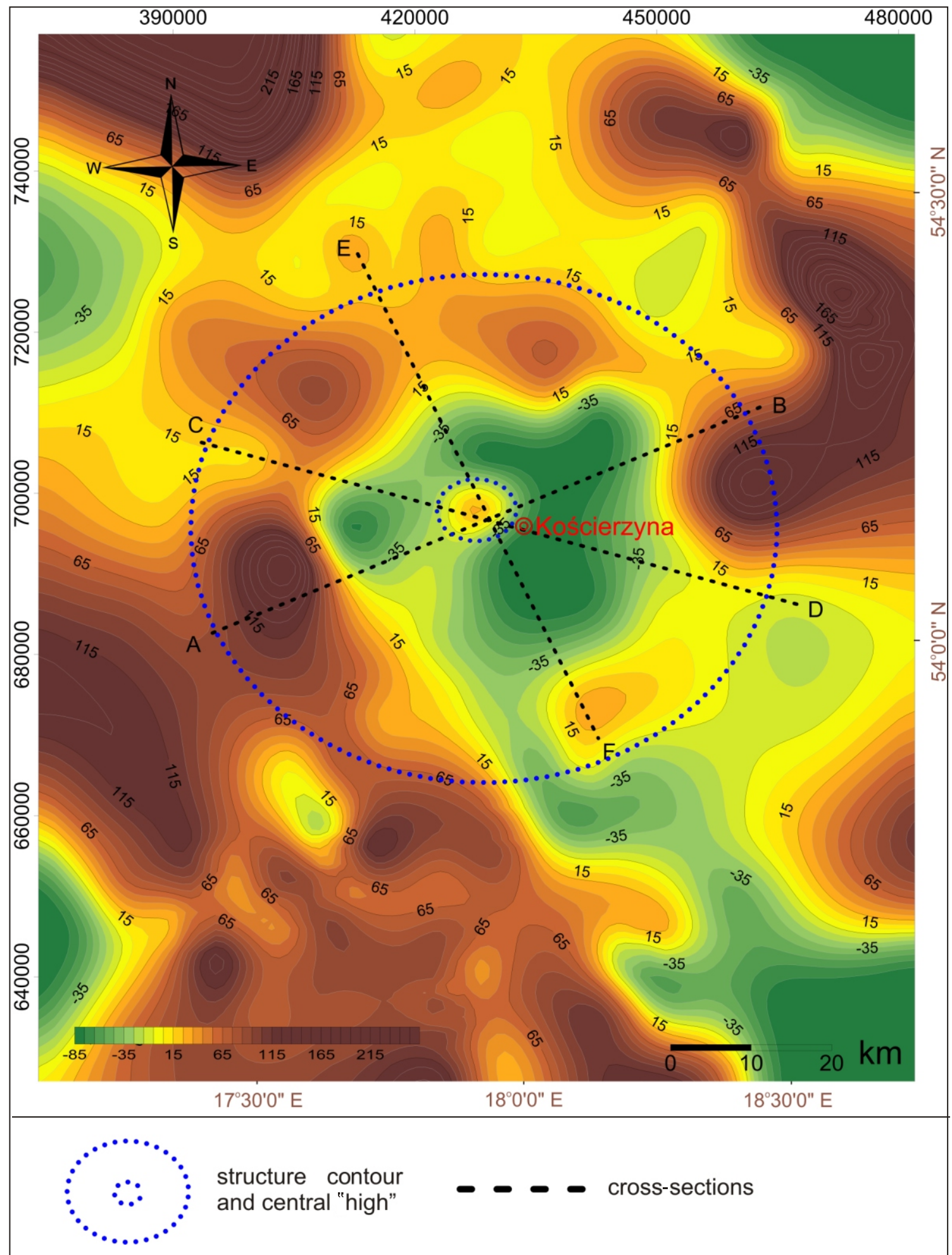

Fig. 4. Map of the pre-Quaternary surface with the limits of the circular/elliptic structure (outer contour) and the central "high" 

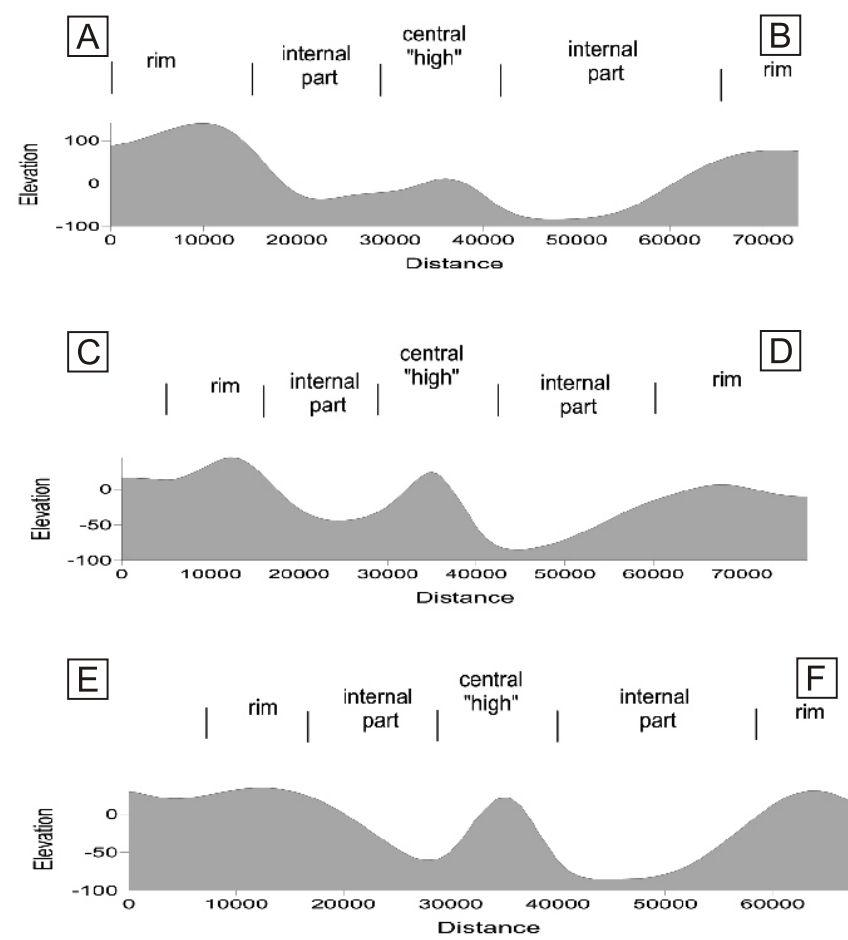

Fig. 5. Morphological cross-sections through the feature under discussion

An alternative hypothesis is an origin of the form due to a meteorite impact (e.g., Doktór et al., 1989). The main argument supporting this hypothesis is the system of lineaments on the surface, radiating from the centre of the structure. The lineaments were recognized from Landsat satellite images (Doktór and Graniczny, 1983). The existence of such a system has been confirmed through DTM analysis carried out for the present study. However, the presence of circular and radial morphological features without any other diagnostic features is not sufficient to interpret it as an impact structure (Koeberl, 2004; Reimold, 2007; French and Koeberl, 2010; Reimold et al., 2014). The topography of the pre-Quaternary surface in the study area is therefore an essential (although indirect) argument in favour of this hypothesis. It clearly shows the bowl-like configuration in the Miocene/Pliocene deposits with characteristic rim-like forms and a central "high". These features interpreted from the pre-Quaternary surface can be recognized even though the data are not optimum due to their uneven distribution. Another factor that influenced the general appearance of the Miocene/Pliocene surface relief is the activity of Pleistocene glaciers, that resulted in erosion and deposition, thus affecting the original morphology of the structure. Nevertheless, the resulting morphology corresponds well with that of well-studied large impact forms (Grieve and Pesonen, 1996; French, 1998; Kenkmann et al., 2014).

The impact hypothesis might become confirmed by geophysical studies of possibly present anomalies. An impact event with the formation of a crater produces distinctive geophysical features. These are reflected in the gravity and magnetic properties of the bedrock (Grieve and Pesonen, 1992). Although there are no direct studies of this type of the proper Kościerzyna structure, some regional geophysical investigations were carried out (Guterch et al., 1999; Młynarski, 2002; Petecki, 2008). A magnetic anomaly has been documented in the marginal part of the East European Craton. This positive magnetic anomaly, described by Petecki (2008) as the "Kościerzyna anomaly", has its equivalent in gravimetric patterns. The centre of the anomaly is located approximately at the centre of a circular structure, but the depth of the source of the anomaly is uncertain (Petecki, 2008). It should be noted that magnetic anomalies associated with large impact structures are commonly fairly variable and unpredictable (French and Koeberl, 2010), so additional detailed studies should be conducted at Kościerzyna as well.

As regards the Kościerzyna structure, a legitimate question arises about the age of the event that led to its creation. If an impact origin is hypothesized, there are two possibilities:

- the impact occurred during the Pleistocene, when the study area was covered by an ice sheet, or;

- the impact had occurred before the area was covered by a Pleistocene land-ice mass, i.e. during the Miocene/Pliocene, at the beginning of Pleistocene, or between two successive glaciations, i.e. when no ice sheet was present.

The first option would have given rise to indirect and uncertain effects. The essential questions are then whether the ice sheet would have been regionally melted away completely and if the impact could have provided a morphological expression. Perhaps, the glacier would have worked as a medium which transfers the energy to the mineral substratum. However, the situation is questionable and requires thorough consideration of the astronomical (as a science concerning extraterrestrial phenomena), glaciological and geological settings.

These aspects should be taken into consideration in the second option as well, but the second case is more likely in the author's opinion, particularly because of the depression: the presumed impact crater is distinguishable in the pre-Quaternary. Moreover, the Quaternary succession contains sediments of almost all glaciations that affected the Polish Lowlands. This indicates that the structure was formed somewhere in a time span from the Miocene to the pre-glacial phase of the Pleistocene.

There are no known craters or impact palaeocraters of this large size, established in relatively unconsolidated sediments or rocks with a low degree of diagenesis. The issue of acquiring and retaining the craters in young unconsolidated sediments was raised several times (Stankowski, 2001; Stankowski et al., 2007; Uścinowicz, 2014). However, none of the cases referred to examples that are tens of kilometres in diameter.

The Mjølnir (Barents Sea) and Silverpit (North Sea) craters are similar to the feature under study (Stewart and Allen, 2002; Dypvik et al., 2006). In both cases, almost horizontal unlithified sediments were hit, and they were subject to sophisticated studies, far more advanced than those on the Kościerzyna structure. There are also craters with diameters of tens of kilometres, which were exposed to glacial processes, but they were formed in a much more lithified sedimentary cover or in magmatic rocks (Juhlin et al., 2012; Schmieder and Jourdan, 2013) and thus more resistant to erosion and other processes that affected them.

The best way to identify impact craters is to combine different types of investigation (Table 2). The Kościerzyna structure meets some diagnostic criteria, like the existence of its morphological patterns. There is also some rough geophysical evidence, but direct geophysical studies are, unfortunately, lacking. What is worse, the structure is nowadays inaccessible for sampling (because of small amount of preserved drill core) and it was developed in lithologies that are unlikely to show diagnostic petrographic indicators of an impact as well as chemical and 
Summary of some diagnostic criteria in the context of impact origin

\begin{tabular}{|c|c|c|}
\hline Criteria & Structure under discussion & Comment \\
\hline \multicolumn{3}{|l|}{ Morphological feature } \\
\hline circular or eliptic form & Yes & $\begin{array}{l}\text { The structure is buried under Pleistocene deposits and has un- } \\
\text { dergone reshaping due to glacial erosion and accumulation }\end{array}$ \\
\hline $\begin{array}{l}\text { morpholineaments (indicating the po- } \\
\text { tential fracture zones) }\end{array}$ & Yes & $\begin{array}{c}\text { Lineaments visible on the surface regarded as a reflexion of } \\
\text { older fracture zones }\end{array}$ \\
\hline \multicolumn{3}{|l|}{ Geological evidence } \\
\hline $\begin{array}{c}\text { shock-deformation features } \\
\text { (e.g., shatter cones and melt breccia) }\end{array}$ & No & \multirow{3}{*}{ The problems have never been studied in the study area } \\
\hline $\begin{array}{c}\text { shock microdeformation features } \\
\text { (e.g., PFs, PDFs) }\end{array}$ & No & \\
\hline $\begin{array}{l}\text { meteorites, micrometeorites, } \\
\text { spherules }\end{array}$ & No & \\
\hline Geophysical evidence & Possible & $\begin{array}{c}\text { A magnetic and gravimetric anomaly has been documented dur- } \\
\text { ing the regional geophysical investigation }\end{array}$ \\
\hline Geochemical and isotopic evidence & No & - \\
\hline
\end{tabular}

isotopic signatures from the projectile. The unconsolidated sediments (target rocks) might show anomalous effects of the impact, but impact structures buried under a $\sim 200 \mathrm{~m}$ thick cover of glacial and interglacial deposits are not known to have been preserved. If future studies confirm the impact origin of the Kościerzyna structure, this structure can be considered as unique, shedding a new light on potential crater-forming and crater-preservation processes.

\section{CONCLUSIONS}

New investigations, which comprise distinguishing the morpholineaments system based on DTM, establishing a pre-Quaternary surface model, and evaluation of available data, allow the following statements and conclusions to be put forward:

1. The existence of a complex circular structure at Kościerzyna and the trends of topographic lineaments have been confirmed.

2. The regional lineaments radiate from the study area and some of them take on a semicircular shape, marking the boundaries of the buried Kościerzyna structure.

3. The analytical work and the construction of a pre-Quaternary surface model indicate the boundaries of the structure and its geometry. The structure is ca. $50 \mathrm{~km}$ in diameter, has rims, an internal plateau, and a "central high".
4. The whole structure is buried under Pleistocene deposits and has undergone reshaping by glacial erosion and accumulation.

5. Some evidence points at an impact origin of the structure. The overall morphological, geological and geophysical evidence supports the impact hypothesis. Direct petrographic, chemical and geophysical evidence is, however, still lacking. Future studies should be carried out to obtain such information.

6. If an impact is considered as the origin of the structure, its age must be Late Miocene, Pliocene or pre-glacial Pleistocene. This is based on the almost complete succession of Pleistocene deposits in the study area.

7. The hypothetical large-scale impact must have induced large environmental changes, at least on a regional scale, and this should also be investigated in the future.

8. A new potential impact structure with a diameter of tens of kilometres would contribute to the insight concerning the frequency of impact events of significant scale.

Acknowledgements. The present study was performed with funds allocated for statutory activity of the Polish Geological Institute - National Research Institute (no. 61.2701.1501.00.0). A. van Loon and anonymous reviewer are thanked for valuable remarks and suggestions that allowed improving the manuscript. The author is also grateful to all those who helped in the preparation of the present contribution.

\section{REFERENCES}

Alsouki, M, Riahi, M.A., Yassaghi, A., 2011. Seismic imaging of sub-circular salt-related structures: evidence for passive diapirism in the Straits of Hormuz, Persian Gulf. Petroleum Geoscience, 17: 101-107.

Bertoni, C., Cartwright, J.A., 2005. 3D seismic analysis of circular evaporites dissolution structures, Eastern Mediterranean. Journal of the Geological Society, 162: 909-926.

Brink, M.C., Waanders, F.B., Bisschoff, A.A., 1997. Vredefort: a model for the anatomy of an astrobleme. Tectonophysics, 270: 83-114.
Czapowski, G., Bukowski, K., 2010. Geology and resources of salt deposits in Poland: the state of the art. Geological Quarterly, 54 (4): 509-518.

Doktór, M., Graniczny, M., 1983. The ring and circular structures on satelitary images - their meaning and origin (in Polish with English summary). Przegląd Geologiczny, 31: 30-36.

Doktór, S., Graniczny, M., Kucharski, R., 1989. Astrobleme of Kościerzyna (in Polish with English summary). Przegląd Geologiczny, 37: 571-573. 
Dypvik, H., Smelror, M., Sandbakken, P., Salvigsen, O., Kaaleson, E., 2006. Traces of the marine Mjolnir impact event. Palaeogeography, Palaeoclimatology, Palaeoecology, 241 621-636.

French, B.M., 1998. Traces of catastrophe. A Handbook of Shock-Metamorphic Effects in Terrestrial Meteorite Impact Structures. LPI Contribution No. 954. Lunar and Planetary Institute, Houston.

French, B.M., Koeberl, C., 2010. The convincing identification of terrestrial meteorite impact structures: what works, what doesn't, and why. Earth-Science Reviews, 98: 123-170.

Gałązka, D., Marks, L., 2009. Geology of the Lower Vistula region, northern Poland. Polish Geological Institute Special Papers, 25: 13-20.

Goulty, N.R., Dobson, A.J., Jones, G.D., Al.-Kindi, S.A., Holland, J.G., 2001. Gravity evidence for diapiric ascent of the Northern Arran Granite. Journal of the Geological Society, 158: 869-876.

Grieve, R.A.F., Pesonen, L.J., 1992. The terrestrial impact cratering record. Tectonophysics, 216: 1-30.

Grieve, R.A.F., Pesonen, L.J., 1996. Terrestrial impact craters: Their spatial and temporal distribution and impacting bodies. Earth, Moon, Planets, 72: 357-376.

Guterch, A., Grad, M, Thybo, H., Keller, G.R., and The POLONAISE Working Group, 1999. POLONAISE '97 - an international seismic experiment between Precambrian and Variscan Europe in Poland. Tectonophysics, 314: 101-121.

Juhlin, C., Sturkell, E., Ebbestad, J.O.R., Lehnert, O., Hogstrom, A.E.S., Meinhold, G., 2012. A new interpretation of the sedimentary cover in the western Siljan Ring area, central Sweden based on seismic data. Tectonophysics, 580: 88-99.

Kenkmann, T., Poelchau, M. H., Wulf, G., 2014. Structural geology of impact craters. Journal of Structural Geology, 62: 156-182.

Koeberl, C., 2004. Remote sensing studies of impact craters: how to be sure? Comptes Rendus Geoscience, 336: 959-961.

Kramarska, R., Kasiński, J., Czapowski, G., Piwocki, M., Słodkowska, B., 2015. The standard section of Neogene deposits from Eastern Pomerania at Łęczyce near Lębork (northern Poland) (in Polish with English summary). Biuletyn Państwowego Instytutu Geologicznego, 461: 193-250.

Marks, L., 2010. Timing of the Late Vistulian (Weichselian) glacial phases in Poland. Quaternary Science Reviews, 44: 81-88.

Marzec, P., Niepsuj, M., Słonka, Ł., Pietsch, K., 2013. Application of 2-D forward seismic modelling for improved imaging of sub-salt Rotliegend strata in Polish basin. Annales Societatis Geologorum Poloniae, 83: 65-80.

Matton, G., Jebrak, M., Lee, J.K.W., 2005. Resolving the Richat enigma: doming and hydrothermal karstification above an alkaline complex. Geology, 33: 665-668.

Młynarski, S., 2002. Seismic refraction investigations in Poland (1964-1978) and their use in continuing studies. Geological Quarterly, 46 (3): 247-253.

Mojski, J.E., 1973. Objaśnienia do Mapy geologicznej Polski 1:200 000, ark. Grudziądz (in Polish). Wydawnictwa Geologiczne, Warszawa

Mojski, J.E., 1978a. Objaśnienia do Mapy geologicznej Polsk 1:200 000, ark. Chojnice (in Polish). Wydawnictwa Geologiczne Warszawa.

Mojski, J.E., 1978b. Objaśnienia do Mapy geologicznej Polski 1:200 000, ark. Słupsk (in Polish). Wydawnictwa Geologiczne, Warszawa.

Mojski, J.E., 1979. Objaśnienia do Mapy geologicznej Polski 1:200 000, ark. Gdańsk (in Polish). Wydawnictwa Geologiczne, Warszawa.

Mojski, J.E., 1980. Vistulian stratigraphy in the glaciated area of the Polish Lowlands. Quaternary Studies in Poland, 2: 77-98.
Petecki, Z., 2008. Magnetic basement in the Pomeranian segment of the Trans-European Suture Zone - NW Poland (in Polish with English summary). Prace Państwowego Instytutu Geologicznego, 191: 1-72.

Petelski, K., 2011. The influence of sub-Quaternary basement on the relief in the eastern part of the Pomerania Lakeland, Poland. Annales Societatis Geologorum Poloniae, 81:105-114.

Pietsch, K., Marzec, P., Niepsuj, M., Krzywiec, P., 2012. The influence of seismic velocity distribution on the depth imaging of the sub-Zechstein horizons in areas affected by salt tectonics: a case study of NW Poland. Annales Societatis Geologorum Poloniae, 82: 263-277.

PohI, J., Stoffler, D., Gall, H., Ernstson, K., 1977. The Ries impact structure. In: Impact and Explosion Cratering (eds. D.J. Roddy, R.O. Pepin and R.B. Merrill): 343-404. Pergamon Press, New York.

Przybylski, B., Badura, J., 2004. May the ring structures in Sudetes have an impact origin (in Polish with English summary)? Przegląd Geologiczny, 52: 971-978.

Reimold, W. U., 2007. The impact crater bandwagon (some problems with the terrestrial impact cratering record). Meteoritics \& Planetary Science, 42: 1467-1472.

Reimold, W.U., Ferriere, L., Deutsch, A., Koeberl, C., 2014. Impact controversies: impact recognition criteria and related issues. Meteoritics \& Planetary Science, 49: 723-731.

Riller, U., 2005. Structural characteristics of the Sudbury impact structure, Canada: impact-induced versus orogenic deformation - a review. Meteoritics \& Planetary Science, 40: $1723-1740$.

Saul, J.M., 1978. Circular structures of large scale and great age on the Earth's surface. Nature, 271: 345-349.

Schmieder, M., Jourdan, F., 2013. The Lappajarva impact structure (Finland): Age, duration of crater cooling, and implication for early life. Geochimica et Cosmochimica Acta, 112: 321-339.

Stankowski, W. 2001. The geology and morphology of the natural reserve "Meteoryt Morasko". Planetary and Space Science, 49: 749-753.

Stankowski, W., Raukas, A., Bluszcz, A., Fedorowicz, S., 2007 Luminescence dating of the Morasko (Poland), Kaali, llumetsa and Tsoorikmae (Estonia) meteorite craters. Geochronometria, 28: $25-29$

Stewart, S.A., Allen, P.J., 2002. A 20-km-diameter multi-ringed impact structure in the North Sea. Nature, 418: 520-523.

Stoffler, D., Artemieva, N.A., Pierazzo, F., Ivanov, B.A., 2001. Ries crater, Germany: geology and numerical modeling of impact cratering. Meteoritics \& Planetary Science, 36 (9): Supplement, A199.

Suuroja, K., Suuroja, S., 2010. The Neugrand meteorite crater on the seafloor of the Gulf of Finland, Estonia. Baltica, 23: 47-58.

Taud, H., Parrot, J.-F., 1992. Detection of circular structures on satellite images. International Journal of Remote Sensing, 13: 319-335.

Turtle, E. P., Pierazzo, E., 1998. Constraints on the size of the Vredefort impact crater from numerical modeling. Meteoritics \& Planetary Science, 33: 483-490.

Uścinowicz, G., 2014. Impact craters and the extraterrestrial matter in their surroundings: case of Morasko (Poland) and Kaali (Estonia). Baltica, 27: 24-31.

Znosko, J., Dadlez, R., Grocholewski, A., Kowalczewski, Z., Ryłko, W., Ryka, W., 1998. Tectonic map of Poland, 1:500 000. In: Tectonic Atlas of Poland (ed. J. Znosko). Polish Geological Institute, Warszawa. 